\title{
Salinity tolerance improvement of in vitro propagated Paulownia tomentosa using proline
}

\author{
Nora Muhammad Youssef*, Khaled Ismail Hashish and Lobna Salah Taha
}

\begin{abstract}
Background: Paulownia tomentosa has been used as an ornamental plant and is still vastly used for this objective and can be utilized for the production of energy, wooden building materials, and paper pulp. The aim was to improve the in vitro propagation ability under salinity stress.

Methodology: This experiment was conducted on Paulownia tomentosa at Tissue Culture Technique Lab., Central Laboratories, Department of Ornamental Plants and Woody Trees, National Research Centre (NRC), Egypt, to examine the micropropagation behavior using different plant growth regulators (BA, Kin, and IBA) and improve the in vitro propagation ability of plant under the effect of salinity levels (500, 1000, 2000, and 4000 ppm) using two concentrations of proline $(0.2$ and $0.4 \mathrm{~g} / \mathrm{l})$.

Results: For in vitro propagation behavior, the best results for both shooting and rooting behaviors were obtained when MS culture medium was supplemented with BA at $0.2 \mathrm{mg} / \mathrm{l}$, and Kin and IBA at $0.1 \mathrm{mg} / \mathrm{l}$. For the improvement of the in vitro propagation ability under salinity stress, the survival was $100 \%$ when the shootlets of Paulownia grown on MS culture medium supplemented with $0.5 \mathrm{~g} \mathrm{NaCl}$ plus 0.2 or $0.4 \mathrm{~g} / \mathrm{l}$ proline and $1 \mathrm{~g} \mathrm{NaCl}$ plus $0.2 \mathrm{~g} / \mathrm{l}$ proline which were similar to control treatment.

Conclusion: Micropropagation ability of Paulownia tomentosa under salinity stress was optimized when the explants were cultured on MS medium supplemented with BA at $0.2 \mathrm{mg} / \mathrm{l}$, and Kin and IBA at $0.1 \mathrm{mg} / \mathrm{l}$ using proline at $0.2 \mathrm{~g} / \mathrm{l}$. This study will help the producers to cultivate Paulownia trees in saline soils up to $1000 \mathrm{ppm}$ such as some new lands which are not suitable for growing other crops.
\end{abstract}

Keywords: Paulownia, Micropropagation, Salinity, and Proline

\section{Background}

Paulownia trees belong to Scrophulariaceae family involve nine species of fast-growing trees that are native to China and East Asia (Ayan et al. 2006). Paulownia tomentosa has been entered into the USA and Europe as an ornamental plant and is still vastly used for this objective. The average height of trees reaches $12 \mathrm{~m}$ and $13.4 \mathrm{~cm}$ of average diameter through 7 years in Bulgaria (Kalmukov 1995). The trees can reach up to $30 \mathrm{~m}$ at

\footnotetext{
* Correspondence: norayousif20@yahoo.com

Ornamental Plants and Woody Trees Department, National Research Centre, Dokki, Giza, Egypt
}

\section{Springer Open}

maturity (Bonner 1995). This high yielding tree can be utilized for the production of energy, wooden building materials, and paper pulp (Bergmann and Moon 1997).

The environmental deterioration causes biotic and abiotic stresses in plants and restricted their growth and development (Shao and Chu 2005). Among the abiotic stresses, salinity and drought are the main stresses that damage crop worldwide (Vinocur and Altman 2005). Rising salinity causes severe harm to plants, including growth inhibition, necrosis, impaired metabolism, and reduction of production and quality (Sivritepe and Eris 1999). Salinity stress cause accumulation of reactive oxygen species (ROS) $\left(\mathrm{O}_{2}\right.$, superoxide radicals; $\mathrm{OH}$, hydroxyl radical;

(c) The Author(s). 2020 Open Access This article is licensed under a Creative Commons Attribution 4.0 International License, which permits use, sharing, adaptation, distribution and reproduction in any medium or format, as long as you give appropriate credit to the original author(s) and the source, provide a link to the Creative Commons licence, and indicate if changes were made. The images or other third party material in this article are included in the article's Creative Commons licence, unless indicated otherwise in a credit line to the material. If material is not included in the article's Creative Commons licence and your intended use is not permitted by statutory regulation or exceeds the permitted use, you will need to obtain permission directly from the copyright holder. To view a copy of this licence, visit http://creativecommons.org/licenses/by/4.0/. 
$\mathrm{H}_{2} \mathrm{O}_{2}$, hydrogen peroxide; and $1 \mathrm{O}_{2}$, singlet oxygen), producing an oxidative stress. Oxidative stress can damage DNA, lipid peroxidation, and inactivate enzymes (Gill and Tuteja 2010).

However, sugars, sugar alcohols, and several other molecules as amino acids, organic acids, or inorganic ions have the ability to improve salt tolerance mechanisms (Munns 2005). Proline acid is a compatible osmolyte that accumulates in many crops under salt stress (Munns and Tester 2008). Proline helps to protect cells of the plant from the negative effects of salt by preserving the osmotic balance, scavenging reactive oxygen species (ROS), and stabilizing subcellular structures, such as proteins and membranes (Ashraf and Foolad 2007). Many reports show the effective role of exogenous proline in osmoregulation of several plant species under salt stress (Lone et al. 1987; Tal and Katz 1980; Wyn et al. 1977).

Plant tissue culture provides beneficial information to illustrate plant response to salt stress. Micropropagation provides greater control than in vivo growth conditions and has the advantage of small scale with monitoring responses of shoot and root in the presence of imposed stress (Shibli et al. 1992). The micropropagation technique of Paulownia species offers a rapid means of producing woody biomass and planting stock for afforestation, and it is an effective method to maintain the genetic gain (Park and Bonga 1992). The success of consecutive micropropagation for many woody plants could be affected by different factors such as plant growth regulators which are the most important ones (Taha et al. 2008).

Paulownia tree is considered as very sensitive to salinity. The aim of the research was to optimize a micropropagation protocol using different plant growth regulators (BA, Kin, and IBA) and improving plant ability to salinity tolerance so that it can be cultivated in the new lands which are not suitable for growing other crops.

\section{Materials and methods}

The experimental work was conducted on Paulownia tomentosa during the years 2018 and 2019 at the Tissue Culture Technique Lab., Central Laboratories, Department of Ornamental Plants and Woody Tress, National Research Centre (NRC), Egypt, to evaluate and improve the in vitro propagation ability of plant under the effect of salinity stress.

\section{Explant source and disinfection}

Nodal explants of Paulownia tomentosa at the Faculty of Agriculture, Ain Shams University, Shobra El-Khyema, Egypt, were taken and washed in septal soap, then rinsed with running tap water for $1 \mathrm{~h}$. The surface disinfection of explant was done under aseptic condition using $70 \%$ ethanol for $1 \mathrm{~min}$, followed by $15 \%(\mathrm{v} / \mathrm{v})$ of Clorox $(\mathrm{NaOCl}$ $5.25 \%$ ) for $10 \mathrm{~min}$, followed by mercuric chloride at $0.2 \%$ $(w / v)$. The explants were rinsed three times with sterile distilled water after each disinfection treatment.

\section{Culture medium}

Explants were cultured on MS medium (Murashing and Skoog, 1962) supplemented with $2.5 \%$ sucrose and $0.7 \%$ agar (w/v) prior to autoclaving at $1.2 \mathrm{~kg} / \mathrm{cm}^{2}$ for $15 \mathrm{~min}$. The $\mathrm{pH}$ of the culture medium was adjusted to 5.8. Culturing was done in $200 \mathrm{ml}$ glass jars containing $25 \mathrm{ml}$ of the medium.

For evaluation of in vitro propagation behavior, plant growth regulators were added to MS culture medium at different concentrations:

Benzlaminopurine (BAP) at 0.2 and $0.4 \mathrm{mg} / \mathrm{l}$ with or without Kin at $0.1 \mathrm{mg} / \mathrm{l}$ and indole-3-butyric (IBA) at 0.1 or $0.2 \mathrm{mg} / \mathrm{l}$.

For evaluation of in vitro propagation ability under salinity stress, the in vitro growth (shooting and rooting) behavior was examined through culturing the nodal explants which were obtained from the most suitable multiplication medium (MS + $0.2 \mathrm{mg} / \mathrm{l} \mathrm{BA}+0.1 \mathrm{mg} / \mathrm{l} \mathrm{Kin} \mathrm{+} \mathrm{0.1} \mathrm{mg/l}$ IBA) under different concentrations of $\mathrm{NaCl}(0.0,500$, $1000,2000,4000 \mathrm{ppm})$. Two concentrations of proline $(0.2$ and $0.4 \mathrm{~g} / \mathrm{l})$ were examined to improve the in vitro propagation ability under salinity stress.

\section{Incubation conditions}

Cultures were incubated under controlled conditions in the growth chamber. The incubation temperature was $24 \pm 2{ }^{\circ} \mathrm{C}$ controlled by a "power" air conditioner. The photoperiod was 16-h light/8-h darkness, controlled automatically. Illumination intensity was 3000 lux from cool fluorescent lamps.

\section{Chemical analysis}

\section{Photosynthetic pigments}

Plant material after multiplication stage was collected, and photosynthetic pigments (chlorophyll a and b) as well as carotenoids were determined in shootlets tissues as $\mathrm{mg} /$ $100 \mathrm{~g}$ fresh weight by using spectrophotometer, according to the procedure achieved by Saric et al. (1967).

\section{Proline determination}

The proline was determined according to Carrilo et al. (2011). A $500-\mu \mathrm{l}$ ethanolic extract $(80 \%$ ethanol) or $100 \mu \mathrm{l}$ of 5-2-1-0.5 and 0.2-mM proline standard solution was completed with up to $400 \mu \mathrm{l}$ of ethanol: water $(40: 60 \mathrm{v} / \mathrm{v})$ is added to $1 \mathrm{ml}$ of reaction mixture (ninhydrin $1 \%(\mathrm{w} / \mathrm{v})$ in acetic acid $60 \%(\mathrm{v} / \mathrm{v})$, ethanol $20 \%(\mathrm{v} / \mathrm{v}))$ and incubated at $95{ }^{\circ} \mathrm{C}$ for $20 \mathrm{~min}$. After that, the mixture was cooled at room temperature and centrifuged 1 min at $10000 \mathrm{rpm}$. The supernatant was read at $520 \mathrm{~nm}$ with UV-spectrophotometer.

Proline in nmol.mg ${ }^{-1}$ FW or in $\mu$ mol.g ${ }^{-1} \mathrm{FW}=$ $\left(\mathrm{Abs}_{\text {extract }}\right.$-blank $) /$ slope $\times \mathrm{Vol}_{\text {extract }} / \mathrm{Vol}_{\text {aliquot }} \times 1 / \mathrm{FW}$ 


\section{Experimental design and data analysis}

The data were analyzed through analysis of variance ANOVA, and the treatments' means were compared for significance by Duncan's new multiple range test at $0.05 \%$ level of probability (Duncan 1955) using COSTATV-63.

\section{Results}

\section{In vitro propagation behavior}

The results presented in Table 1 and Fig. 1 show the in vitro shooting and rooting ability of Paulownia tomentosa under the effect of different plant growth regulators (BA, Kin, and IBA) concentrations. The best results for both shooting and rooting behaviors were obtained when MS culture medium was supplemented with $\mathrm{BA}$ at $0.2 \mathrm{mg} / \mathrm{l}$, at Kin and IBA at $0.1 \mathrm{mg} / \mathrm{l}$ which lead to the highest survived explants $(100 \%)$, number of shootlets (5.67), longest shootlets $(6.96 \mathrm{~cm})$, and highest rooting percent $(98.33 \%)$ as compared to control which was MS medium without growth regulators and caused lowest values. The data also revealed that using of low concentration of BA $(0.2 \mathrm{mg} / \mathrm{l})$ combined with Kin $(0.1$ $\mathrm{mg} / \mathrm{l}$ ) and IBA at 0.1 or $0.2 \mathrm{mg} / \mathrm{l}$ were favored for improving the in vitro propagation ability of Paulownia comparing with other treatments. This indicates the role of all used plant growth regulators for attaining the internal hormone balance that led to the best results.

Means within a column having the same letters are not significantly different according to Duncan's multiple range test (DMRT) at $5 \%$ level

\section{Effect of salinity stress on micropropagated plants}

The growth characters as survival, shoot number, shoot length, and leaves' number, also the rooting parameters as rooting percentage, roots number, and root length of Paulownia tomentosa were significantly affected by the $\mathrm{NaCl}$ treatments. As shown in Table 2, all in vitro

Table 1 In vitro propagation ability of Paulownia tomentosa effecting by plant growth regulators

\begin{tabular}{|c|c|c|c|c|c|c|}
\hline \multicolumn{3}{|c|}{ Character } & \multirow{3}{*}{$\begin{array}{l}\text { Survival } \\
\%\end{array}$} & \multirow{3}{*}{$\begin{array}{l}\text { Shootlets } \\
\text { number/ } \\
\text { explant }\end{array}$} & \multirow{3}{*}{$\begin{array}{l}\text { Shootlets } \\
\text { length }(\mathrm{cm})\end{array}$} & \multirow[t]{3}{*}{ Rooting\% } \\
\hline \multicolumn{3}{|c|}{ PGR (mg/l) } & & & & \\
\hline $\mathrm{BA}$ & Kin & $\mathrm{IBA}$ & & & & \\
\hline 0 & 0 & 0 & 33.33 e & $1.00 \mathrm{e}$ & $3.23 \mathrm{fg}$ & $50.00 \mathrm{f}$ \\
\hline 0.2 & 0 & 0 & $66.67 \mathrm{~d}$ & $1.33 \mathrm{de}$ & $3.33 f$ & $28.83 \mathrm{~g}$ \\
\hline 0.4 & 0 & 0 & 33.33 e & $0.97 \mathrm{e}$ & $2.80 \mathrm{~g}$ & $25.33 \mathrm{~h}$ \\
\hline 0.2 & 0 & 0.1 & $75.00 \mathrm{c}$ & $1.83 \mathrm{~cd}$ & $4.83 \mathrm{~d}$ & 86.67 e \\
\hline 0.4 & 0 & 0.2 & $76.33 \mathrm{~d}$ & 1.60 cde & $4.16 \mathrm{e}$ & $67.33 \mathrm{e}$ \\
\hline 0.2 & 0.1 & 0.1 & $100.00 \mathrm{a}$ & $5.67 \mathrm{a}$ & $6.96 \mathrm{a}$ & 98.33 a \\
\hline 0.2 & 0.1 & 0.2 & 86.67 b & $4.33 b$ & $6.10 \mathrm{~b}$ & $89.33 b$ \\
\hline 0.4 & 0.1 & 0.1 & $72.67 \mathrm{~cd}$ & $3.67 \mathrm{~b}$ & $5.40 \mathrm{c}$ & $82.00 \mathrm{~d}$ \\
\hline 0.4 & 0.1 & 0.2 & 75.00 C & $2.33 c$ & $5.10 \mathrm{~cd}$ & $80.00 \mathrm{~d}$ \\
\hline
\end{tabular}

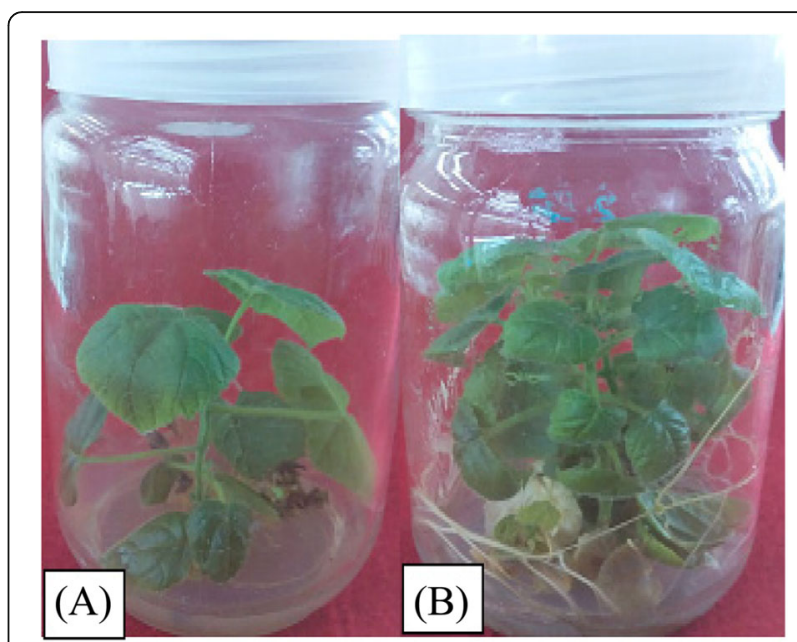

Fig. 1 In vitro propagation of Paulownia tomentosa under the effect of different plant growth regulators (BA, Kin, and IBA) concentrations. a MS free of hormones and $\mathbf{b} \mathrm{MS}+\mathrm{BA}$ at $0.2 \mathrm{mg} / \mathrm{l}$, and $\mathrm{Kin}$ and $\mathrm{IBA}$ at $0.1 \mathrm{mg} / \mathrm{l}$

growth characters were decreased with increasing $\mathrm{NaCl}$ concentrations from 500 to $4000 \mathrm{ppm}$. The $500 \mathrm{ppm}$ $\mathrm{NaCl}$ did not reduce the survival $(100 \%)$ and produced an increase of the shoot number (5.67) as compared to control. At $4000 \mathrm{ppm} \mathrm{NaCl}$, the number of shootlets, shoot length, and leaves' number was adversely affected and gave only half values approximately of that of control, whereas the survival percentage was decreased to $61 \%$. The rooting parameters were decreased significantly from 500 and $1000 \mathrm{ppm} \mathrm{NaCl}$ and were absent at 2000 and $4000 \mathrm{ppm} \mathrm{NaCl}$. Concentrations of $\mathrm{NaCl}$ at 500 and $1000 \mathrm{ppm}$ resulted in a significant reduction in rooting percentage (22.22 and $11.11 \%)$, roots number (0.67 and 0.33 ), and roots' length (11.78 and $5 \mathrm{~mm}$ ), respectively, compared with control treatment; however, no rooting occurred when explants were grown on 2000 and $4000 \mathrm{ppm}$ of $\mathrm{NaCl}$.

Means within a column having the same letters are not significantly different according to Duncan's multiple range test (DMRT) at $5 \%$ level

Table 3 demonstrates the effect of proline on alleviation of salinity stress on the micropropagated plants, with increasing salinity concentrations using different proline level, and all parameters were reduced. The survival was $100 \%$ when the shootlets of Paulownia grown on MS culture medium supplemented with $0.5 \mathrm{~g} \mathrm{NaCl}$ plus 0.2 or $0.4 \mathrm{~g}$ proline and $1 \mathrm{~g} \mathrm{NaCl}$ plus $0.2 \mathrm{~g}$ proline which were similar to control treatment. Applying $0.5 \mathrm{~g}$ of $\mathrm{NaCl}$ plus 0.2 proline gave the best values after the control for each of the number of shootlets/explant, length of shootlets, and number of nodes/shootlet (1.33, 57.92, and $41.33 \mathrm{~mm}$, respectively). All previous parameters were declined sharply with increasing salinity levels. 
Table 2 In vitro shooting and rooting behaviors of Paulownia under the effect of salinity stress

\begin{tabular}{llllllll}
\hline Salinity $(\mathrm{ppm})$ & Survival\% & Shootlets number/explant & Shootlet length $(\mathrm{mm})$ & Nodes number /shootlet & Rooting\% & Roots number & Root length (mm) \\
\hline 0.00 & $100 \mathrm{a}$ & $5.00 \mathrm{a}$ & $26.28 \mathrm{a}$ & $30.50 \mathrm{a}$ & $100 \mathrm{a}$ & $8.50 \mathrm{a}$ & $23.33 \mathrm{a}$ \\
500 & $100 \mathrm{a}$ & $5.67 \mathrm{a}$ & $23.36 \mathrm{~b}$ & $18.67 \mathrm{c}$ & $22.22 \mathrm{~b}$ & $0.67 \mathrm{~b}$ & $11.78 \mathrm{~b}$ \\
1000 & $88.89 \mathrm{ab}$ & $3.67 \mathrm{~b}$ & $17.47 \mathrm{~cd}$ & $14.33 \mathrm{~d}$ & $11.11 \mathrm{~b}$ & $0.33 \mathrm{~b}$ & $5.00 \mathrm{bc}$ \\
2000 & $77.78 \mathrm{ab}$ & $3.67 \mathrm{~b}$ & $18.59 \mathrm{c}$ & $20.67 \mathrm{~b}$ & 0.0 & 0.0 & 0.0 \\
4000 & $61.11 \mathrm{~b}$ & $2.33 \mathrm{c}$ & $15.42 \mathrm{~d}$ & $15.00 \mathrm{~cd}$ & 0.0 & 0.0 & 0.0 \\
\hline
\end{tabular}

The shootlets were produced roots even applying $1 \mathrm{~g}$ of sodium chloride and using the higher concentration of it prevents root formation. These results indicate that Paulownia plants can grow at $1000 \mathrm{ppm}$ of $\mathrm{NaCl}$, but the higher concentration of $\mathrm{NaCl}$ causes poor growth or death. The use of proline with salt stress improved in vitro growth slightly.

Means within a column having the same letters are not significantly different according to Duncan's multiple range test (DMRT) at $5 \%$ level

\section{Photosynthetic pigments under salinity stress}

Figure 2 indicates the effect of salt stress by applying different levels of sodium chloride on the chlorophyll content of the Paulownia leaves under study, including chlorophyll a and $b$. The results show a reverse relationship between salt level and chlorophyll a and b contents. Whenever the level of $\mathrm{NaCl}$ was increased, chlorophyll content was decreased. Chlorophyll a and $\mathrm{b}$ reach to the lowest contents $(71.42$ and $25.51 \mathrm{mg} / 100 \mathrm{~g} \mathrm{F.W}$. at 4000 ppm of $\mathrm{NaCl}$ ) compared to control (271.90 and 175.90 $\mathrm{mg} / 100 \mathrm{~g} \mathrm{~F}$.W., respectively). A statistical analysis demonstrates that the observed differences were significant. By following carotenoids content through the exposure of the Paulownia explants to salt stress, it appears from Fig. 2 that salt stress $(\mathrm{NaCl})$ was an inhibiting agent for the formation of carotenoids inside the stressed leaves, where the carotenoids' content was decreased. The least carotenoids content was appeared with the level $4000 \mathrm{ppm}$ of $\mathrm{NaCl}$ $(54.80 \mathrm{mg} / 100$ g F.W.), whereas the highest content
(606.7 mg/100 g F.W.) appeared in control leaves. There were gradual decreases with increasing salinity levels.

\section{Photosynthetic pigments under different salinity levels and proline concentrations}

Data illustrated in Fig. 3 mention the role of proline concentration in accumulated pigments content in shootlets of Paulownia that grown under salinity stress. The highest chlorophyll a and b contents (528.4 and $273.1 \mathrm{mg} / 100 \mathrm{~g} \mathrm{F.W.}$.) were obtained in shootlets grown on MS culture medium supplemented with $0.5 \mathrm{~g} \mathrm{NaCl}$ plus $0.2 \mathrm{~g}$ proline followed by the treatment of $\mathrm{NaCl} 1.0$ g plus 0.2 proline which caused also the highest carotenoids content $(397.1 \mathrm{mg} / 100 \mathrm{~g}$ F.W.) comparing with other treatments. This indicates the role of proline when it was used at low concentration in increasing chlorophyll content under salinity stress.

\section{Proline content under salinity stress}

The data presented in Fig. 4 shows the response of proline content in the shootlets of Paulownia to salt stress. The content of proline ranged between 0.277 and $0.443 \mathrm{nmol} /$ $\mathrm{mg}$. The salinity treatments increased the content of proline as compared with the control. A slight increase was recorded with the low concentrations of $\mathrm{NaCl}$ (500 and $1000 \mathrm{ppm}$ ), then marked increases were recorded using $\mathrm{NaCl}$ at 2000 and $4000 \mathrm{ppm}$. Where the proline content reached its maximum value $(0.443 \mathrm{nmol} / \mathrm{mg})$ when the explants were grown on the highest concentration of $\mathrm{NaCl}$, compared to that for the untreated explants.

Table 3 Alleviation of salinity stress on the micropropagated Paulownia under the effect of proline concentration

\begin{tabular}{|c|c|c|c|c|c|c|c|}
\hline Character treatment & Survival \% & $\begin{array}{l}\text { Shootlets number/ } \\
\text { explant }\end{array}$ & Shootlet length (mm) & $\begin{array}{l}\text { Nodes number/ } \\
\text { shootlet }\end{array}$ & Rooting\% & $\begin{array}{l}\text { Roots } \\
\text { number }\end{array}$ & $\begin{array}{l}\text { Root length } \\
(\mathrm{mm})\end{array}$ \\
\hline Control & $100.00 \mathrm{a}$ & $2.44 \mathrm{a}$ & $51.67 \mathrm{a}$ & $46 \mathrm{a}$ & $100 \mathrm{a}$ & $7.25 \mathrm{~b}$ & $115 \mathrm{a}$ \\
\hline $0.5 \mathrm{~g} \mathrm{NaCl}+0.2 \mathrm{~g}$ proline & $100.00 \mathrm{a}$ & $1.61 \mathrm{~b}$ & $57.92 \mathrm{a}$ & $41.33 \mathrm{~b}$ & $100 \mathrm{a}$ & $12 \mathrm{a}$ & $108.3 \mathrm{a}$ \\
\hline $0.5 \mathrm{~g} \mathrm{NaCl}+0.4 \mathrm{~g}$ proline & $100.00 \mathrm{a}$ & $1.50 \mathrm{bc}$ & $27.00 \mathrm{~b}$ & $12.67 \mathrm{c}$ & $55.67 \mathrm{~b}$ & $6.98 \mathrm{~b}$ & 90.00 a \\
\hline $1.0 \mathrm{~g} \mathrm{NaCl}+0.2 \mathrm{~g}$ proline & $100.00 \mathrm{a}$ & $1.33 \mathrm{bcd}$ & $27.11 \mathrm{~b}$ & $12.33 \mathrm{~cd}$ & $22.22 b$ & $0.67 c$ & $11.78 \mathrm{c}$ \\
\hline $1.0 \mathrm{~g} \mathrm{NaCl}+0.4 \mathrm{~g}$ proline & 89.00 a & 1.28 bcde & $20.11 b c$ & $12.00 \mathrm{~cd}$ & 66.67 a & $7.33 \mathrm{~b}$ & $51.67 \mathrm{~b}$ \\
\hline $2.0 \mathrm{~g} \mathrm{NaCl}+0.2 \mathrm{~g}$ proline & $78.00 \mathrm{ab}$ & 1.17 cde & $19.11 \mathrm{bc}$ & $12.00 \mathrm{~cd}$ & 0 & 0 & 0 \\
\hline $2.0 \mathrm{~g} \mathrm{NaCl}+0.4 \mathrm{~g}$ proline & $61.33 b$ & $1.11 \mathrm{de}$ & $15.00 \mathrm{c}$ & 9.17 cde & 0 & 0 & 0 \\
\hline $4.0 \mathrm{~g} \mathrm{NaCl}+0.2 \mathrm{~g}$ proline & $38.67 \mathrm{c}$ & $1.00 \mathrm{de}$ & $15.33 \mathrm{C}$ & $8.67 \mathrm{de}$ & 0 & 0 & 0 \\
\hline $4.0 \mathrm{~g} \mathrm{NaCl}+0.4 \mathrm{~g}$ proline & $22.00 \mathrm{c}$ & $0.92 \mathrm{e}$ & $15.33 \mathrm{c}$ & $6.67 \mathrm{e}$ & 0 & 0 & 0 \\
\hline
\end{tabular}




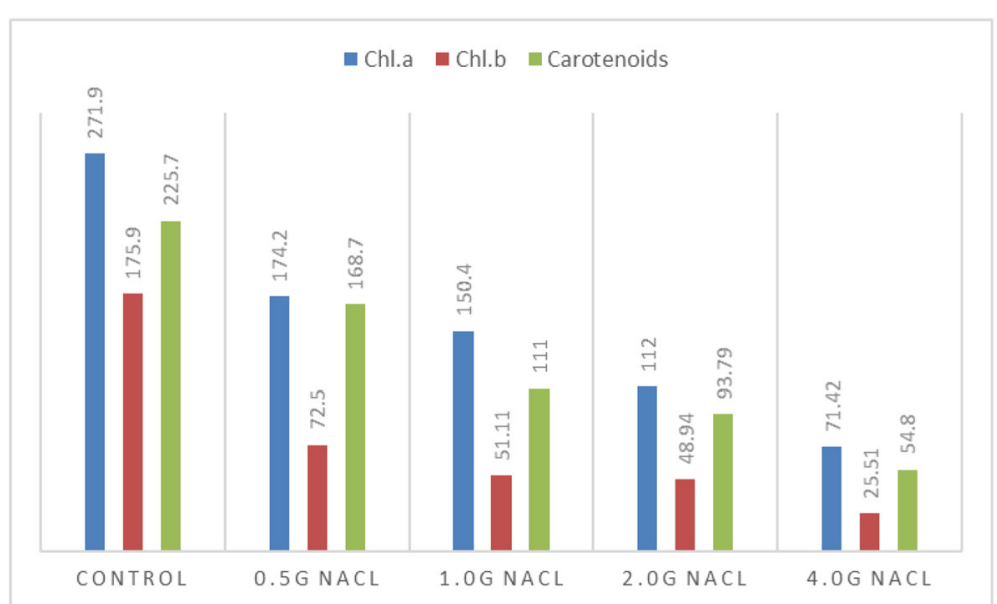

Fig. 2 Photosynthetic pigments contents (mg/100 g F.W.) in Paulownia tementosa shootlets effecting by different salinity levels

\section{Proline content under salinity stress and proline} concentration

Figure 5 shows that the highest proline content $(0.377$ $\mathrm{nmol} / \mathrm{mg}$ ) resulted in shootlets grown on MS culture medium supplemented with $4 \mathrm{~g} \mathrm{NaCl}$ plus $0.2 \mathrm{~g}$ proline followed by those obtained from $\mathrm{NaCl} 2.0 \mathrm{~g}$ plus 0.2 proline which gave $0.335 \mathrm{nmol} / \mathrm{mg}$ as compared to control which gave the lowest value $(0.121 \mathrm{nmol} / \mathrm{mg})$.

\section{Discussion}

In this study, the response of in vitro propagation could be improved by adding plant growth regulators (PGR) to the culture medium (Table 1). Confirmed results pointed out that different concentrations of BAP, Kin, or IBA showed a significant effect on bud sprouting of Paulownia kawakemii during three repeated subcultures (Abd El-Kader and Abou El-Ghit 2015). They mentioned also that adding IBA to the culture medium had a promotion effect on bud break, especially with a low concentration of BAP. The inhibition of adventitious meristem elongation could reduce the number of shoots as a result of using a high concentration of BAP (Borchetia et al. 2009).

Concerning the effect of salinity stress on in vitro propagation ability (Table 2), explants' growth of apple rootstock was severely affected by salinity treatments. High salinity gave the reduction in shoot number, shoot length, rooting percentage, root number, and root length (Bahmani et al. 2012). Shahid et al. (2011) noticed the reduction in the length of the shoot with an increasing level of $\mathrm{NaCl}$. This might be explained as the inadequate photosynthesis caused by stomatal closure and the reduction of carbon assimilation rate under salt stress

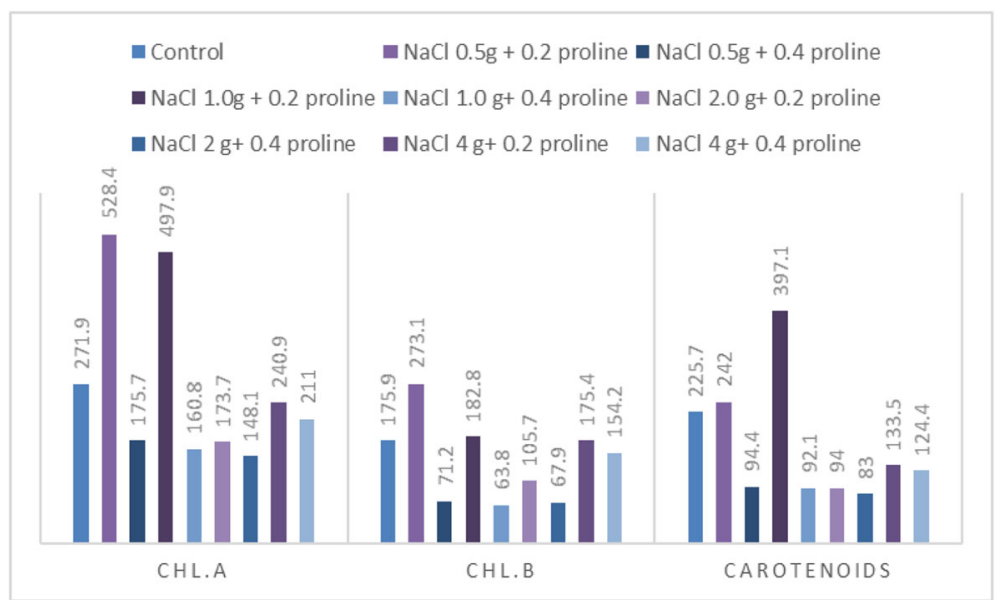

Fig. 3 Photosynthetic pigments contents (mg/100 g F.W) in Paulownia tementosa shootlets under different salinity levels and proline concentration 


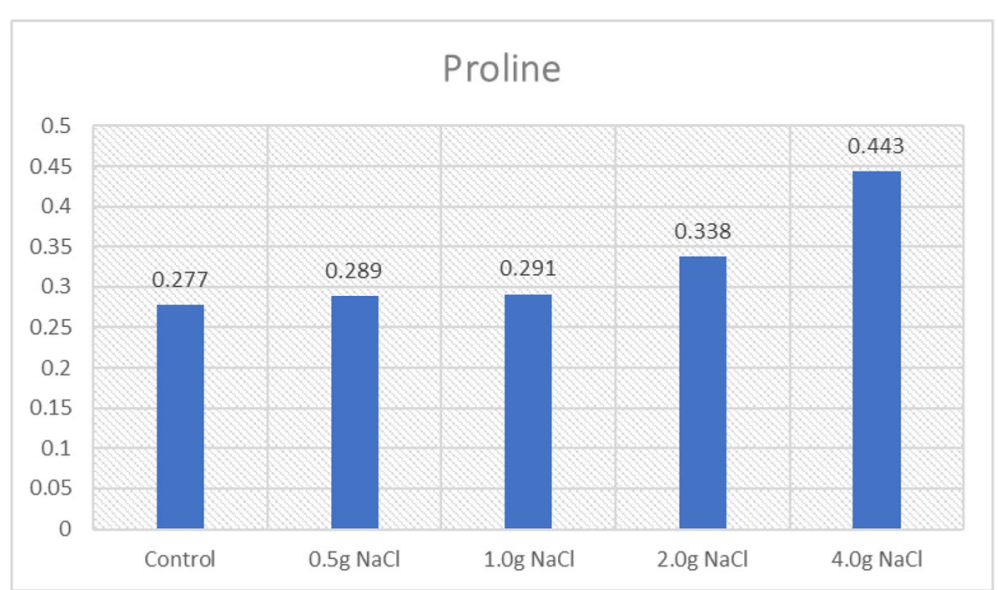

Fig. 4 Proline content $(\mathrm{nmol} / \mathrm{mg})$ in Paulownia shootlets effecting by different salinity levels

(Ben Ahmed et al. 2009). Miladinova et al. (2013) reported that the leaf number, root, and stem length in Paulownia plants were reduced with increasing salinity concentration.

Concerning the results in Table 3, using proline with salt stress improved in vitro growth slightly. Proline is a predominant organic molecule that acts as an intercessor of osmotic adjustment under salinity stress, a sink for energy, a stabilizer of sub-cellular structures, and even a stress linked signal. It is also contributed to cell osmoregulation and protection of proteins during dehydration, and under stress conditions, it can act as an enzymatic regulator (Rontain et al. 2002).

As results in Figs. 2 and 3, the pigments (chlorophyll $\mathrm{a}, \mathrm{b}$, and $\beta$-carotene) in Paulownia imperialis leaves were significantly reduced when exposed to a high level of $\mathrm{NaCl}$ (Astorga and Meléndez 2010).
The response of proline to salt stress (Figs. 4 and 5) may due to these osmoprotectants that acts an important role in decrease stress-induced cellular acidification and osmotic adjustments and stabilizes sub-cellular structures for recovery (Tan et al. 2008). Recent studies also suggested that the protective role of proline depends on protecting the protein turnover machinery against stress damage and upregulating stress-protective proteins (Khedr et al. 2003).

\section{Conclusion}

MS culture medium that was supplemented with BA at $0.2 \mathrm{mg} / \mathrm{l}$, and Kin and IBA at $0.1 \mathrm{mg} / \mathrm{l}$ gave the best results for both shooting and rooting behaviors of Paulownia tomentosa. The plantlets were able to grow in a saline condition (1000 ppm), and the growth could be improved slightly using proline.

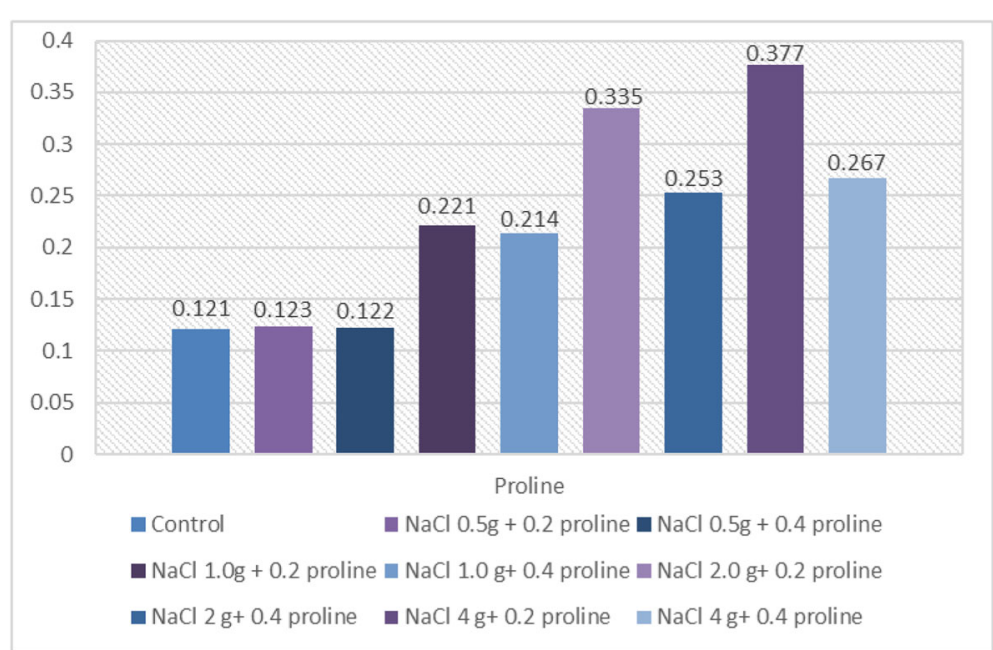

Fig. 5 Proline content $(\mathrm{nmol} / \mathrm{mg})$ in Paulownia shootlets effecting by different salinity levels and proline concentrations 


\section{Acknowledgements}

The authors are greatly thankful to the National Research Centre, $33 \mathrm{El}$ Bohouth st. (formal El Tahrir st.), Dokki. Giza, Egypt, P.O.12622, to provide the funding credit of this work.

\section{Authors' contributions}

NMY and LST performed the in vitro experiment, analyzed the data, and contributed to writing and reviewing the paper. Kh I H performed a part of in vitro experiment. The authors read and approved the final manuscript.

\section{Authors' information}

Dr. Nora Muhammad Youssef Researcher at the Department of Ornamental Plant and Woody Trees, Agricultural and Biological Res. Division, National Research Centre (NRC), P.O. Box 12622 Dokki, Giza, Egypt.

Dr. Khaled Ismail hashish assistant prof. at the Department of Ornamental Plant and Woody Trees, Agricultural and Biological Res. Division, National Research Centre (NRC), P.O. Box 12622 Dokki, Giza, Egypt.

Dr. Lobna Salah Taha prof. at the Department of Ornamental Plant and Woody Trees, Agricultural and Biological Res. Division, National Research Centre (NRC), P.O. Box 12622 Dokki, Giza, Egypt.

\section{Funding}

This work was supported and funded by the National Research Centre.

\section{Availability of data and materials}

The datasets generated and/or analyzed during the current study are included in this published.

\section{Ethics approval and consent to participate}

Not applicable

\section{Consent for publication}

Not applicable

\section{Competing interests}

The authors declare that they have no competing interests.

Received: 22 October 2019 Accepted: 25 May 2020

Published online: 05 June 2020

\section{References}

Abd El-Kader EM, Abou El-Ghit HM (2015) In vitro growth behavior of Paulownia kawakamii hybrid under nutrient media and plant growth regulators effect. Biolife 3(4):910-916

Ashraf M, Foolad MR (2007) Roles of glycinebetaine and proline in improving plant abiotic stress tolerance. Environ Exp Bot 59:206-216

Astorga GIA, Meléndez LA (2010) Salinity effects on protein content, lipid peroxidation, pigments, and proline in Paulownia imperialis (Siebold \& Zuccarini) and Paulownia fortunei (Seemann \& Hemsley) grown in vitro Electronic Journal of Biotechnology 13(5):1-15

Ayan S, Sivacioglu A, Bilir N (2006) Growth variation of Paulownia Sieb. and Zucc. species and origins at the nursery stage in Kastamonu-Turkey. J Environ Biol 27:499-504

Bahmani R, Gholami M, Mozafari AA, Alivaisi R, (2012) Effects of salinity on in vitro shoot proliferation and rooting of apple rootstock MM.106. World Applied Sciences Journal 17(3):292-295

Ben Ahmed C, Ben Rouina B, Sensoy S, Boukhriss M, Abdullah FB (2009) Saline water irrigation effects on antioxidant defense system and proline accumulation in leaves and roots of field-grown olive. J Agric Food Chem 57: $11484-11490$

Bergmann BA, Moon HK (1997) In vitro adventitious shoot production in Paulownia. Plant cell reports 16:315-319

Bonner FT (1995) Paulownia tomentosa (Thunb.) Sieb. \& Zucc. Ex Steud, royal Paulownia. In: Burns, R.M. and Honcala, B.H. eds. Silvics of North America, Hardwoods Agric Handbk 654 Washington DC. USDA Forest Service 2:501502

Borchetia S, Das SC, Handique PJ, Das S (2009) High multiplication frequency and genetic stability for commercialization of the three varieties of micropropagated tea plants (Camellia spp.). Scientia Horticulturae 120(4):544550

Duncan DB (1955) Multiple range and multiple F-tests. Biometrices 11:1-42
Gill SS, Tuteja N (2010) Reactive oxygen species and antioxidant machinery in abiotic stress tolerance in crop plants. Plant Physiology and Biochemistry 48(12):909-930

Kalmukov K (1995) Influence of primary density upon the process of growth and development of some fast-growing tree species used for biomass. In: Ed. V.N. Brezin 70 Years Forestry education in Bulgaria. Jubilee Sciences Session, 7-9. Vl., Sofi a, v. I, pp. 129-137.

Khedr AH, Abbas MA, Wahid AA, Quick WP, Abogadallah GM (2003) Proline induces the expression of salt-stress-responsive proteins and may improve the adaptation of Pancratium maritinum L to salt stress. J Exp Bot 54:25532562

Lone MI, Kueh JS, Wyn, R.J. Bright SJ (1987) Influence of proline and glycinebetaine on salt tolerance of cultured barley embryos. Journal of Experimental Botany 38:479-490

Miladinova K, Ivanova K, Georgieva T, Geneva M, Markovska Y (2013) The salinity effect on morphology and pigments content in three paulownia clones grown ex vitro. Bulgarian Journal of Agricultural Science 19(2):52-56

Munns R (2005) Genes and salt tolerance: bringing them together. Tansley Rev New Phytol 167:645-663

Munns R, Tester M (2008) Mechanisms of salinity tolerance. Annu Rev Plant Biol 59:651-681

Murashing T, Skoog F (1962) A revised medium for rapid growth and bioassays with tobacco tissue culture. Physiol. plant. 15:473-497

Park YS, Bonga JM (1992) Conifer micropropagation: its function in tree improvement programs. In: Ahuja MR (ed) Micropropagation of woody plants. Ed. MG. Ahuja, Kluwer Academic, Dordrecht, pp 457-470

Rontain D, Basset G, Hanson AD (2002) Metabolic engineering of osmoprotectant accumulation in plants. Metab Eng 4:49-56

Saric MR, Kastrori-Cupina T, Gergis I (1967) Chlorophyll determination Univ. Unoven Sadu-Prakitikum is Kiziologize Bilika-Beagrad, Haucua Anjiga 215

Shahid MA, Pervez MA, Balal RM, Ahmad R, Ayyub CM (2011) Salt stress effects on some morphological and physiological characteristics of okra (Abelmoschus esculentus L.). Soil Env 30: 66

Shao HB, Chu LY (2005) Plant molecular biology in China: opportunities and challenges. Plant Molec Biol Rep 23:345-358

Shibli RA, Spomer LA, Smith MAL (1992) Osmotic adjustment and growth response of three Chrysanthemum Morifolium Ramat. Cultivars to Osmotic Stress Induced in vitro. J Plant Nutr 15:1373-1381

Sivritepe N, Eris A (1999) Determination of salt tolerance in some grapevine cultivars (Vitis vinifera L.) under in vitro conditions. Turk J Biol 23:473-485

Taha LS, Soad MM Ibrahim and Farahat MM (2008). A micropropagation protocol of Paulownia kowakamii through in vitro culture technique. Australian Journal of Basic and Applied Sciences, 2(3): 594- 600

Tal M, Katz A (1980) Salt tolerance in the wild relatives of the cultivated tomato: the effect of proline on the growth of callus tissue of Lycopersicon esculentum and L. peruvianum under salt and water stress. Z Pflanzenphysiol Bd 98:283-288

Tan J, Zhao H, Hong J, Han Y, Li H, Zhao W (2008) Effects of exogenous nitric oxide on photosynthesis, antioxidant capacity and proline accumulation in wheat seedlings subjected to osmotic stress. World J Agric Sci 4:307-313

Vinocur B, Altman A (2005) Recent advances in engineering plant tolerance to abiotic stress: achievements and limitations. Curr Opinion Biotechn 16:123132

Wyn RG, Storey R, Leigh RA, Ahmad N, Pollard A (1977) A hypothesis on cytoplasmic osmoregulation. In: Regulation of Cell Membrane Activities in Plants. (Eds.): E. Marr \& O Ciferri Elsevier/North-Holland Biomedical Press Amsterdam 121-136

\section{Publisher's Note}

Springer Nature remains neutral with regard to jurisdictional claims in published maps and institutional affiliations. 